\title{
The influence of bronchial asthma control level on the quality of life indices
}

\author{
0. V. Herasymova ${ }^{1}$, T. L. Protsiuk ${ }^{1}$, L. O. Protsiuk ${ }^{1}$, N. M. Surkova ${ }^{2}$, L. D. Kotsur ${ }^{1}$, \\ 0. V. Kuleshov ${ }^{1}$
}

${ }^{1}$ National Pirogov Memorial Medical University, Vinnytsia, Ukraine ${ }^{2}$ Vinnytsia Regional Children's Clinical Hospital, Ukraine

Key words: bronchial asthma, quality of life, children.

Pathologia 2018; 15 (2), 204-209

DOl:

10.14739/2310-1237.

2018.2.141394

E-mail:

rossata@ukr.net
Objective - to study the indices of general and specific quality of life in schoolchildren, depending on the level of bronchial asthma control.

Materials and methods. Quality of life parameters of 189 in-patients with BA, aged 6-17 years and 95 controls were studied. Parallel questioning with subsequent analysis of quality of life indices in 189 parents of BA children and 95 parents of the control group children was performed. General QL was evaluated using PedsQL (Pediatric Quality of Life Inventory 4.0). Specific quality of life was evaluated using specific quality of life questionnaire for the children ill with bronchial asthma - PAQLQ (Pediatric Asthma Quality of Life Questionnaire). Statistical analysis of the data obtained was done by variance statistical methods using the standard program package of multivariate statistical analysis Statistica 6.0

Results. The study found the index of physical functioning to be 43.6 [31.3-62.5] points in the children with UC BA, 53.1 [37.5-68.2] points in those with PC BA, being significantly lower as compared to the control group children - 79.6 [56.0-100.0] points $(P<0.001)$. Physical functioning index in the children with UC BA was 1.7 times lower as compared to those with C BA. Comparison of the indices in those with PC BA - 53,1 [37.5-68.2] points and C BA - 74.1 [50.0-76.0] points, showed that physical activity in the children with PC BA was significantly lower as compared to those with $C$ BA $(P<0.001)$. The analysis showed no significant difference between the answers of the children with asthma and their parents. No significant difference between the answers of healthy children's parents and the children themselves was revealed as well $(P>0.05)$. The cumulative index of $Q L$ was dependent on the level of BA control. It was 2.5 [1.4-3.6] points in the children with UC BA, being significantly lower as compared to those with $\mathrm{PC} B A-3.9$ [2.8-4.9] points, and $C$ $B A-6.2[5.6-6.8]$ points $(P<0.001)$; and in the children with $P C B A$ this index was significantly lower as compared to those with $\mathrm{C} B A(P<0.01)$.

Conclusions. Along with traditional methods of assessment of respiratory function and laboratory indices of inflammatory process activity in bronchial asthma, study of physical and mental health, social activity, general wellbeing and many other parameters of quality of life, as well as the influence of treatment on these parameters should be carried out.
Киючові слова: бронхіальна астма, якість життя, Аіти.

Патологія. - 2018. T. 15, № 2(43). C. 204-209

\section{Вплив рівня контролю бронхіальної астми на показники якості життя в дітей}

\section{О. В. Герасимова, Т. А. Процюк, А. О. Процюк, Н. М. Суркова, А. А. Коцур, О. В. Кулешов}

Мета роботи - вивчити показники загальної та специфічної якості життя (ЯЖ) в дітей шкільного віку залежно від рівня контролю БА.

Матеріали та методи. Під час дослідження вивчали параметри якості життя 189 хворих на БА від 6 до 17 років і 95 дітей контрольної групи. Паралельно здійснили опитування та аналіз показників якості життя 189 батьків дітей, які хворі на БА, та 95 батьків дітей контрольної групи. Оцінювання загальної ЯЖ виконали з використанням загального опитувальника оцінювання якості життя в педіатрії - PedsQL (Pediatric Quality of Life Inventory 4.0). Оцінювання специфічної якості життя проводили за допомогою специфічного опитувальника з якості життя дітей, які хворі на бронхіальну астму - PAQLQ (Pediatric Asthma Quality of Life Questionnaire). Статистичне опрацювання результатів виконали за допомогою методів варіаційної статистики з використанням стандартного пакета програм багатомірного варіаційно-статистичного аналізу Statistica 6.0.

Результати. Встановили, що показник фрізичного функціонування в дітей із НК БА становив 43,6 [31,3-62,5] бала, в дітей із ЧК БА - 53,1 [37,5-68,2] бала та був вірогідно меншим порівняно з дітьми контрольної групи - 79,6 [56,0-100,0] бала $(p<0,001)$. Показник фізичного функціонування в дітей із НК БА був в 1,7 раза меншим порівняно з дітьми, у котрих була К БА, а порівнюючи цей показник у дітей із ЧК БА - 53,1 [37,5-68,2] бала та К БА - 74,1 [50,0-76,0] бала, встановили, що фізична активність у дітей із ЧК БА виявилася вірогідно нижчою порівняно з К БА (p < 0,001). Аналіз оцінювання показників загальної якості життя дітьми та їхніми батьками залежно від рівня контролю БА дав можливість встановити, що вірогідної різниці між відповідями дітей з астмою та їхніми батьками не було, а також не встановили вірогідної різниці між відповідями батьків здорових дітей і самими дітьми ( $p>0,05)$. Сумарний показник ЯЖ мав особливості залежно від рівня контролю БА. Так, у дітей із НК БА він становив 2,5 [1,4-3,6] бала та був вірогідно меншим порівняно з дітьми з ЧК БА - 3,9 [2,8-4,9] бала та К БА - 6,2 [5,6-6,8] бала ( $<<0,001)$, в дітей із ЧК БА цей показник був вірогідно меншим порівняно з дітьми з К БА $(p<0,01)$.

Висновки. Поряд із традиційними методами оцінювання функції зовнішнього дихання та лабораторних показників активності запального процесу при бронхіальній астмі необхідно проводити обстеження фрізичного та психічного здоров'я, соціальної активності, загального добробуту й багато інших показників якості життя, а також впливу лікування на них. 


\section{Влияние уровня контроля бронхиальной астмы на показатели качества жизни у детей}

\section{Е. В. Герасимова, Т. ^. Процюк, ^. А. Процюк, Н. М. Суркова, А. А. Коцур, А. В. Кулешов}

Цель работы - изучить показатели общего и специфического качества жизни (КЖ) у детей школьного возраста в зависимости от уровня контроля БА.

Материалы и методы. В ходе исследования изучали параметры качества жизни 189 больных БА детей в возрасте от 6 до 17 лет и у 95 детей контрольной группы. Параллельно проводили опрос и анализ показателей качества жизни 189 родителей детей, больных БА, и 95 родителей детей контрольной группы. Оценку общего КЖ проводили с использованием общего опросника оценки качества жизни в педиатрии - PedsQL (Pediatric Quality of Life Inventory 4.0). Оценку специфического качества жизни проводили с помощью специфического опросника по качеству жизни детей, больных бронхиальной астмой - PAQLQ (Pediatric Asthma Quality of Life Questionnaire). Статистическая обработка полученных результатов проведена с помощью методов вариационной статистики с использованием стандартного пакета программ многомерного вариационно-статистического анализа Statistica 6.0.

Результаты. Установлено, что показатель физического функционирования у детей с НК БА составил 43,6 [31,3-62,5] балла, у детей с ЧК БА - 53,1 [37,5-68,2] балла и был достоверно меньшим по сравнению с детьми контрольной группы - 79,6 [56,0-100,0] балла ( $<$ < 0,001). Показатель фризического фрункционирования у детей с НК БА был в 1,7 раза меньше по сравнению с детьми, у которых диагностирована К БА, а при сравнении данного показателя у детей с ЧК БА и К БА $(53,1$ [37,5-68,2] и 74,1 [50,0-76,0] балла соответственно), установлено, что фризическая активность у детей с ЧК БА оказалась достоверно ниже по сравнению с К БА $(p<0,001)$. Анализ оценки показателей общего качества жизни детьми и их родителями в зависимости от уровня контроля БА позволил установить, что достоверной разницы между ответами детей с астмой и их родителями не было, а также не установлено достоверной разницы между ответами родителей здоровых детей и самими детьми ( $p>0,05)$. Установлено, что суммарный показатель КЖ зависел от уровня контроля БА. Так, у детей с НК БА он был достоверно меньшим по сравнению с детьми с ЧК БА и К БА $(2,5[1,4-3,6]$ по сравнению с 3,9 [2,8-4,9] и 6,2 [5,6-6,8] балла соответственно, $p<0,001)$.

Выводы. Наряду с традиционными методами оценки функции внешнего дыхания и лабораторных показателей активности воспалительного процесса у больных БА необходимо проводить обследование физического и психического здоровья, социальной активности, общего благополучия и других показателей качества жизни, а также влияния лечения на эти показатели.

\section{Topicality}

Bronchial asthma (BA) is one of the most prevalent chronic diseases of the respiratory organs. In recent years the world scientists have been searching for ways to achieve and maintain BA control, to elaborate effective and safe therapy methods as well as to study the influence of therapy on the quality of life [1]. Every year the criteria of BA diagnostics and treatment are reviewed and improved, but many issues are still unsolved [2].

Chronic course of the disease, attacks of expiratory dyspnea, awakening at night, poor exercise capacity, necessity of constant availability of first aid drugs, limitations in occupation choice and social activity - all these factors greatly affect quality of life in the children with BA [3].

Over $30 \%$ of children suffering from BA experience communicative limitations and adaptation difficulties, and every third sick child considers himself different from the children of his age [4]. These characteristic features, typical of adolescence, can influence the attitude of the child to the disease and its treatment $[5,6]$.

The impact of the disease extends to emotional, physical and social aspects of the patients' life. Associated depressive disorders greatly affect the quality of life $(\mathrm{QL})$ of BA children, being indicative of great significance of psycho-emotional state in the children suffering from asthma [7].

Quality of life in BA patients is influenced much by the period of disease course. Exacerbation of BA considerably limits physical activity, enforces the importance of physical and emotional problems, reduces the vitality, influences the mental health, decreases social activity and worsens the patient's subjective perception of his general state condition. In recent decade attention is being increasingly focused on the problem of quality of life in $\mathrm{BA}$ and its impact on general state of health $[2,6-8]$. The concept of BA therapy has been changed: improvement of quality of life has become its aim along with the relief of symptoms and effective disease control.

\section{Objective}

To study the indices of general and specific quality of life in schoolchildren, depending on the level of bronchial asthma control.

\section{Materials and methods}

Quality of life parameters of 189 in-patients with BA, aged 6-17 years, treated at Pulmonology Department of Vinnytsia Regional Children's Clinical Hospital and 95 controls were studied. Parallel questioning with subsequent analysis of quality of life indices in 189 parents of BA children and 95 parents of the control group children was performed. General QL was evaluated using PedsQL (Pediatric Quality of Life Inventory 4.0), developed by J. Varni in 1999, USA [9]. The questionnaire PedsQL consisted of 23 questions, united in the following scales: physical functioning (8 items), emotional functioning (5 items), social functioning (5 items), school functioning (5 items). The questionnaire included two forms: for the children and for the parents. Modules for the children and those for the parents were similar in contents but differed somewhat in the forms of questions. Total score was calculated by 100 -point scale after recoding - the higher the score, the higher quality of life. Specific quality of life
Киючевые слова: бронхиальная астма, качество жизни, Аети.

Патология. - 2018. -

T. 15, № 2(43). -

C. 204-209 


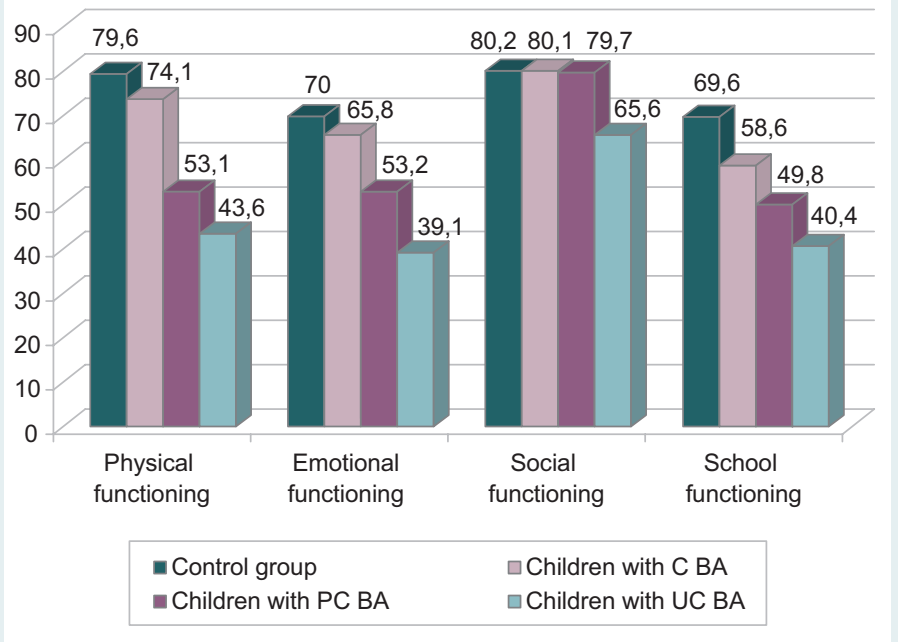

Fig. 1. Indicators of the general quality of life in children depending on the level of control of asthma (points). the median (Me), lower and upper quartiles [LQ25-UQ75] were established. Two unrelated groups were compared using Mann-Whitney U-test. Two related samples were compared using Wilcoxon T-test. All P values of less than 0.05 were considered to indicate statistical significance. Correlation analysis with calculation of Spearman rank correlation $(r)$ was used to establish the relationship between the studied indices.

\section{Results and discussion}

The study found the index of physical functioning to be 43.6 [31.3-62.5] points in the children with UC BA, 53.1 [37.5-68.2] points in those with PC BA, being significantly lower as compared to the control group children -79.6 [56.0-100.0] points $(P<0.001)$ (Fig. 1).

Besides, physical functioning index in the children with UC BA was 1.7 times lower as compared to those with $C$ BA. Comparison of the indices in those with $P C$ BA-53.1 [37.5-68.2] points and C BA-74.1 [50.0-76.0] points, showed that physical activity in the children with PC BA was significantly lower as compared to those with $C B A(P<0.001)$, while no statistical difference between physical functioning index in the children with $\mathrm{PC} B A$ and UC BA was found $(P>0.05)$.

It should be noted that the study revealed negative correlation relationship between uncontrolled course of $B A$ and physical functioning index $(r=-0.41 ; P<0.001)$. Thus, the more uncontrolled course of $B A$, the lower was physical activity of sick children, a finding that is similar to results published from previous studies conducted in Serbia [11] and Iran [12].

The indices of emotional functioning in the patients with UC BA, PC BA and C BA were 39.1 [20.0-50.0], 53.2 [46.0-70.0] and 65.8 [40.0-80.0] points, respectively, being significantly lower as compared to the control group $(P<0.001)$, which was indicative of considerable worsening of the patients' emotional state in the absence of control over the disease symptoms. Significant difference in functioning index was revealed in the children with UC BA - 39.1 [20.0-50.0] points, and in those with C BA $65.8[40.0-80.0]$ points $(P<0.01)$.

Similarly, Indian study concluded that mild to moderate QOL impairment occurred in activity domain (mean score 5.17) and emotional domain (mean score 5.00) [13].

Statistical analysis found negative correlation relationships both between uncontrolled course of BA and emotional functioning index $(r=-0.30 ; P<0.001)$, and between extreme cases seeking for emergency medical aid and this index value $(r=-0.42 ; P<0.001)$. Thus, the more visits requiring emergency medical aid, the worse was the emotional state of BA children.

Social functioning indices were evaluated, and it was found to be 65.6 [30.0-90.0] points in the children with UC BA, being significantly lower as compared to actually healthy children $-80.2[68.0-100.0]$ points $(P<0.05)$, indicating the presence of social adaptation problems in the children with UC BA. No significant difference in this index in other groups of comparison was found $(P>0.05)$.

Negative correlation relationship between the frequency of hospitalization and social functioning index was established in the study $(r=-0.22 ; P<0.001)$. In this 
Table 1. Indicators of the general quality of life in children depending on age (points), Me [LQ25-UQ75]

\begin{tabular}{l|l|l|l|l|l|l|l|l|}
\multirow{2}{*}{$\begin{array}{l}\text { Data general } \\
\text { quality of life }\end{array}$} & \multicolumn{3}{l}{ Control group } & \multicolumn{2}{l|}{ Children with C BA } & \multicolumn{2}{l|}{ Children with PC BA } & \multicolumn{2}{l}{ Children with UC BA } \\
\cline { 2 - 10 } & $\mathbf{6 - 1 0}$ years & $\mathbf{1 1 - 1 7}$ years & $\mathbf{6 - 1 0}$ years & $\mathbf{1 1 - 1 7}$ years & $\mathbf{6 - 1 0}$ years & $\mathbf{1 1 - 1 7}$ years & $\mathbf{6 - 1 0}$ years & 11-17 years \\
\hline PF & 79.6 & 81.5 & 68.7 & 76.1 & 59.3 & 52.4 & 43.7 & 44.6 \\
& {$[60.5-100.0]$} & {$[56.2-96.8]$} & {$[53.0-75.0]$} & {$[50.0-75.0]$} & {$[50.1-68.7]$} & {$[50.1-68.7]^{*}$} & {$[31.2-62.5]$} & {$[34.3-53.2]$} \\
EF & 70.1 & 70.0 & 65.5 & 63.2 & 57.8 & 51.8 & 36.4 & 38.1 \\
& {$[60.0-100.0]$} & {$[60.0-90.0]$} & {$[58.0-75.0]$} & {$[50.0-75.0]$} & {$[50.0-70.0]$} & {$[46.8-62.6]^{*}$} & {$[25.0-50.0]$} & {$[20.0-50.0]$} \\
Soc F & 85.0 & 78.8 & 76.4 & 78.5 & 76.3 & 78.0 & 66.4 & 64.9 \\
& {$[68.0-100.0]$} & {$[68.0-100.0]$} & {$[65.0-100.0]$} & {$[65.0-100.0]$} & {$[70.0-85.0]$} & {$[68.0-85.0]$} & {$[30.0-85.0]$} & {$[28.0-90.0]$} \\
Sch F & 71.2 & 69.0 & 63.0 & 56.1 & 56.8 & 50.0 & 43.3 & 13.0 \\
& {$[65.0-95.0]$} & {$[65.0-100.0]$} & {$[50.0-80.0]$} & {$[50.0-80.0]$} & {$[45.0-70.0]$} & {$[45.0-70.0]^{*}$} & {$[20.0-5.0]$} & {$[19.1-55.0]$} \\
\hline
\end{tabular}

$*: \mathrm{P}<0.05$ - significance of difference of indices compared to the age group 6-10 years; PF: Physical functioning; EF: Emotional functioning; Soc F: Social functioning; SchF: School functioning.

Table 2. Indices of the specific quality of life in children depending on the level of control of asthma (points), Me [LQ25-UQ75]

\begin{tabular}{|c|c|c|c|}
\hline Indices specific quality of life & Children with $\mathrm{C}$ BA $(\mathrm{n}=35)$ & Children with PC BA $(n=30)$ & Children with UC BA $(n=124)$ \\
\hline Symptoms & $5.7[4.2-6.3]$ & $3.6[2.3-4.6]^{*}$ & $2.1[1.1-4.2]^{* \#}$ \\
\hline Physical activity & $6.9[5.8-6.7]$ & $4.3[3.6-5.4]^{*}$ & $2.2[1.0-3.8]^{\star \#}$ \\
\hline Emotional state & $6.4[5.9-6.9]$ & $4.2[3.4-5.2]^{\star}$ & $3.1[2.0-3.5]^{\star \#}$ \\
\hline Cumulative index of specific QL & $6.2[5.6-6.8]$ & $3.9[2.8-4.9]^{*}$ & $2.5[1.4-3.6]$ *\# \\
\hline
\end{tabular}

*: significance of difference indices compared to C BA P $<0.001$; \#: significance of difference indices compared to PC BA P $<0.001$.

case, the higher hospitalization frequency of the children, the lower was their social adaptation.

The index of school functioning was 40.4 [25.0-75.0], 49.8 [45.0-70.0] and $58.7 \pm 1.20$ points in the children with UC BA, PC BA and C BA, respectively, being significantly lower as compared to the controls - 69.6 [68.0-100.0] points $(P<0.001)$. There was significant difference between school functioning index in the children with C BA $-58.7 \pm 1.20$ and UC BA $(P<0.05)$, while it was similar in the patients with UC BA and PC BA $(P>0.05)$.

Negative correlation relationship between uncontrolled course of BA and school functioning index $(r=-0.32 ; P<0.001)$ and frequency of hospitalizations $(r=-0.22 ; P<0.001)$ was found. Thus, the more uncontrolled course of BA and the higher hospitalization frequency, the lower was school functioning index.

Dean B.B., Calimlim B.M. et al. [14] concluded that $70 \%$ children with uncontrolled asthma versus $45 \%$ with controlled asthma missed school, with a median of 6 days versus 4 days missed respectively (during the study period).

The indices of general QL in junior and senior schoolchildren were evaluated and compared in the study. Physical functioning index in the children aged 11-17 with PC BA was 52.4 [50.1-68.7] points, emotional functioning index - 51.8 [46.8-62.6] points, and school functioning index - 50.0 [45.0-70.0] points, being significantly lower as compared to the children of 6-10 years with PC BA59.3 [50.1-68.7] points, 57.8 [50.0-70.0] points, 56.8 [45.0-70.0] points, respectively $(P<0.05)$. As to the social functional index, it was similar in both age groups of children with PC BA (Table 1).

Thus, senior schoolchildren with PC BA had lower physical activity, worse emotional state and more problems at school as compared to junior schoolchildren with PC BA. No significant difference in indices of general $\mathrm{QL}$ in junior and senior schoolchildren with UC BA and C BA was found $(P>0.05)$. Indices of physical activity, emotional state, social adaptation and study at school were considerably decreased in both age categories of children with UC BA, this being caused by the absence of control over the symptoms of the disease.

Chromá J, Slaný J. concluded that the worst quality of life was found among children in the age group of 5-7 years. The mean quality of life of asthmatic children is 74.41 , a statistically significant difference between the physical (78.81) and psychosocial (72.06) dimensions of health. No statistically significant difference in the quality of life was found between the asthmatic and healthy children [15].

Significant differences in estimation of QL of the sick child and his close relatives are presented in the literature [15-17]. In our study, perception of general QL indices by the children with various levels of BA control and their parents was analyzed. The analysis showed no significant difference between the answers of the children with asthma and their parents. No significant difference between the answers of healthy children's parents and the children themselves was revealed as well $(P>0.05)$. Thus, the parents of BA children with various levels of control, as well as their sick children, had similar perception of quality of life indices.

After the detailed study of indices of general QL in BA children with various level of control and their comparison with the control group, our aim was to analyze the indices of specific QL in BA children and to establish their characteristic features, depending on the level of BA control. Along with the evaluation of limitations in physical activity and emotional state in BA children, the impact of disease symptoms (attacks of asphyxia, dyspnea, cough, wheezing, sensation of chest tightness, labored expiration, sleep disorders, weakness) on the QL of those children was estimated, and cumulative index of specific QL was determined. The index "symptoms of disease" was found to be 2.1 [1.1-4.2] and 3.6 [2.3-4.6] points in children with UC BA and PC BA, respectively, being significantly lower as compared to the patients with $C$ $\mathrm{BA}-5.7[4.2-6.3]$ points $(\mathrm{P}<0.001)$. This index was also significantly lower in the children with UC BAas compared to those with PC BA (Table 2). 
The analysis of physical activity limitations in BA children of various levels of control demonstrated that this index was 2.2 [1.0-3.8] and 4.3 [3.6-5.4] points in the patients with UC BA and PC BA, being significantly lower as compared to those with C BA - 6.9 [5.8-6.7] points $(P<0.001)$. Besides, physical activity in the children with UC BA was limited to significantly greater level than in those with $\mathrm{PC} B A(P<0.001)$.

The emotional state index in the children with UC BA was 3.1 [2.0-3.5] points, being significantly lower as compared to those with $\mathrm{PC} B A-4,2$ [3.4-5.2] points and C BA - 6.4 [5.9-6.9] points $(P<0.001)$; and in children with $\mathrm{PC} B A$ this index was also lower than in the patients with $C B A(P<0.001)$.

Matsunaga N.Y. et al. [17] concluded that the CA and the PCA groups, when compared with the NCA group, showed higher values for the overall PAQLQ score and all PAQLQ domains (activity limitation, symptoms, and emotional function; $P<0.001$ for all). Quality of life appears to be directly related to asthma control and asthma severity in children and adolescents, being better when asthma is well controlled and asthma severity is lower.

The cumulative index of QL was dependent on the level of BA control. It was 2.5 [1.4-3.6] points in children with UC BA, being significantly lower as compared to those with $\mathrm{PC} B A-3.9$ [2.8-4.9] points, and C BA-6.2 [5.6-6.8] points $(P<0.001)$; and in children with $P C B A$ this index was significantly lower as compared to those with $C B A(P<0.01)$.

While, the data obtained by M. S. Al-Gewely et al [5] showed the overall PAQLQ score ranged between 2.22 and 6.61 with a mean $\pm S D$ of $4.08 \pm 1.0$. Uncontrolled asthma was associated with the lowest $Q$ oL points $(P \leq 0.01)$. Users of systemic steroids had significantly lower overall PAQLQ score, score of symptoms, score of emotional function than non-users $(P<0.05)$. Difficulty in obtaining the drugs significantly adversely affects the patient $Q$ oL points apart from that of activity limitation $(P<0.05)$.

Assessment of indices of specific QL in children with BA made it possible to carry out the patients' state monitoring in the course of treatment, to determine the impact of treatment on various components of $\mathrm{QL}$ as well as to compare the efficacy of different therapy methods in the children with UC BA.

\section{Conclusions}

The study of QL in sick children is one of major directions in modern medicine, being an integral part of complex analysis of novel diagnostic methods, treatment and prevention of bronchial asthma.

The indices of physical, emotional, social and school functioning are significantly lower in the children with uncontrolled course of bronchial asthma.

Senior schoolchildren with PC BA have more problems with physical activity, emotional state and studies at school, as compared to junior schoolchildren with PC BA, while considerable decrease in indices of physical activity, emotional state, social adaptation and study at school in both age categories of children is observed, this being caused by the absence of control over the symptoms of the disease.
The parents of BA children with various levels of control, as well as their sick children, have similar perception of indices of general quality of life.

The perspectives of further scientific research in this direction is to study the best ways of rehabilitation in patients with BA.

Conflicts of Interest: authors have no conflict of interest to declare. Конфмікт інтересів: віАсутній.

\section{Information about authors:}

Herasymova O. V., MD, PhD, Assistant of the Department of Pediatrics №1, National Pirogov Memorial Medical University, Vinnytsia, Ukraine.

Protsiuk T. L., MD, PhD, DSc, Associate Professor

of the Department of Pediatrics №1, National Pirogov Memorial Medical University, Vinnytsia, Ukraine.

Protsiuk L. O., MD, PhD, Assistant of the Department of Hygiene and Ecology, National Pirogov Memorial Medical University, Vinnytsia, Ukraine.

Surkova N. M., Allergist, Vinnytsia Regional Children's Clinical Hospital, Ukraine.

Kotsur L. D., MD, PhD, Associate Professor Department of Propedeutics of Pediatric Diseases with Patient Care, National Pirogov Memorial Medical University, Vinnytsia, Ukraine.

Kuleshov O.V., MD, PhD, Associate Professor of the Department of Propedeutics of Pediatric Diseases with Patient Care, National Pirogov Memorial Medical University, Vinnytsia, Ukraine.

\section{Відомості про авторів:}

Герасимова О. В., канА. меА. наук, асистент каф. педіатрії №1, Вінницький національний медичний університет імені М. І. Пирогова, Україна.

Процюк Т. ^., А-р меА. наук, Аоцент каф. педіатрії №1, Вінницький національний медичний університет імені М. І. Пирогова, Україна.

Процюк ^. О., канА. меА. наук, асистент каф. загальної гігієни та екології, Вінницький національний медичний університет імені М. І. Пирогова, Україна.

Суркова Н. М., мікар-алерголог, Вінницька обласна Аитяча клінічна мікарня, Україна.

Коцур $\wedge$. А., канА. меА. наук, Аоцент каф. пропеАевтики Аитячих захворювань з АогляАом за хворими Аітьми, Вінницький національний медичний університет імені М. І. Пирогова, Україна.

Кулешов О. В., канА. меА. наук, Аоцент каф. пропедевтики Аитячих захворювань з АогляАОм за хворими Аітьми, Вінницький національний медичний університет імені М. І. Пирогова, Україна.

\section{Сведения об авторах:}

Герасимова Е. В., канА. меА. наук, ассистент каф. педиатрии №1, Винницкий национальный медицинский университет имени Н. И. Пирогова, Украина.

Процюк Т. ^., А-р меА. наук, Аоцент каф. пеАиатрии №1, Винницкий национальный медицинский университет имени Н. И. Пирогова, Украина.

Процюк $\bigwedge$. А., канА. меА. наук, ассистент каф. общей гигиены и экологии, Винницкий национальный меАицинский университет имени Н. И. Пирогова, Украина.

Суркова Н. М., врач-аммерголог, Винницкая областная Аетская клиническая больница, Украина.

Коцур $\wedge$. А., канА. меА. наук, Аоцент каф. пропеАевтики детских заболеваний с уходом за больными Аетьми, Винницкий национальный медицинский университет имени Н. И. Пирогова, Украина.

Кулешов А. В., канА. меА. наук, доцент каф. пропедевтики Аетских заболеваний с уходом за больными детьми, Винницкий национальный медицинский университет имени Н. И. Пирогова, Украина. 
References

[1] Gopal, S., \& Rai, A. (2016) Parental Stress and Quality of life in Parents of Children with Bronchial Asthma. IJHSR., 6(6), 293-300.

[2] Protsiuk, T. L. (2013) Yakist zhyttia khvorykh na bronkhialnu astmu ditei ta chynnyky, shcho vplyvaiut na nei [The quality of life of children with bronchial asthma and the factors affecting on it]. Current issues in pharmacy and medicine: science and practice, 3(13), 66-68. [in Ukrainian].

[3] Wander, A., Bhargava, S., Pooni, P. A., Kakkar, S. \& Arora, K. (2017) Quality of life in children with bronchial asthma. J PediatrRes., 4(06), 382-387.

[4] Elshazly, H. M., Mahalawy, I. El., Gabr, H. M., Abd El Naby, S. A., \& Elzoghby, E. E. (2015) Quality of life among asthmatic children attending the Outpatient Clinic in Menoufia University Hospital. Menoufia Med J., 28, 442-6.

[5] Al-Gewely, M. S., El-Hosseiny, M., Abou Elezz, N. F., El-Ghoneimy, D. H. \& Hassan, A. M. (2013) Health-related quality of life in childhood bronchial asthma. Egypt J. Pediatr. Allergy Immunol., 11(2), 83-93.

[6] Luskin, A. T., Chipps, B. E., Rasouliyan, L., Miller, D. P., Haselkorn, T., \& Dorenbaum, A. (2014). Impact of asthma exacerbations and asthma triggers on asthma-related quality of life in patients with severe or difficult-to-treat asthma. J. Allergy Clin Immunol Pract., 2(5), 544-52. e1-2. doi: 10.1016/j.jaip.2014.02.011.

[7] Heethal, J. P., Khine, K. M., Kenneth, W. C.F., Kum, Y. Z., Irigo, C. I., Nurul, S., \& Sanjeev, S. (2014). A Survey on the quality of life in patients with bronchial asthma in an outpatient clinic in Malaysia, Br. J. Med. Med. Res., 4(5), 1187-1194. doi: 10.9734/BJMMR/2014/5985.

[8] Klymenko, V. A., \& Karpushenko, Yu. V. (2014) Yakist zhyttia ditei z alerhichnymy zakhvoriuvanniamy [The quality of life of children with allergic diseases]. Astma ta alerhia, 3; 27-29. [in Ukrainian].

[9] Varni, J. W., Burwinkle, T. M., Seid, M., \& Skarr, D. (2003). The PedsQL ${ }^{\mathrm{TM}} 4.0$ as a pediatric population health measure: Feasibility, reliability, and validity. Ambul. Pediatrics, 3(6), 329-341.

[10] Juniper, E. F., Guyatt, G. H., Ferrie, D. H., Ferrie, P. J., Griffith, L. E., \& Townsed, M. (1996). Measuring quality of life in the parents of children with asthma. Quality of Life Research, 5(1), 27-34

[11] Cerović, S., Zivković, Z., Milenković, B., Stojanović, J. J, Bajec, A. O., Vukaŝinović, Z., \& Veković, V. (2009). The Serbian version of the pediatric asthma quality of life questionnaire in daily practice. J. Asthma., 46(9), 936-9. doi: 10.3109/02770900903265812.

[12] Zandieh, F., Moin, M. \& Movahedi, M. (2006). Assessment of quality of life in Iranian asthmatic children, young adults and their caregivers. Iran J. Allergy Asthma Immunol, 5(2), 79-83. doi: 05.01/ijaai.7983.

[13] Nair, S., Nair, S. \& Sundaram, K. R. (2014)A prospective study to assess the quality of life in children with asthma using the pediatric asthma quality of life questionnaire. Indian J. Allergy Asthma Immunol., 28(1), 13-8.

[14] Dean, B. B., Calimlim, B. M., Kindermann, S. L., Khandker, R. K., \& Tinkelman, D. (2009) The impact of uncontrolled asthma on absenteeism and health-related quality of life. J. Asthma., 46(9), 861-6. doi: 10.3109/02770900903184237.

[15] Chromá, J., \& Slaný, J. (2011) Quality of life of children with bronchial asthma disease. Cas. Lek. Cesk., 150(12), 660-4.

[16] Trzcieniecka-Green, A., Bargiel-Matusiewicz, K., Wilczyńska, A., \& Omar, H. A. Quality of Life of Parents of Children with Asthma (2015). International Journal of Child and Adolescent Health, 8(3), 351-355.

[17] Matsunaga, N. Y., Gonçalves de Oliveira Ribeiro, M. A., Bredda Saad, I. A. Morcillo, A. M., Ribeiro, J. D. \& Dalbo Contrera Toro, A. (2015) Evaluation of quality of life according to asthma control and asthma severity in children and adolescents. J. Bras. pneumol., 41(6), 206-2011. doi: 10.1590/S1806-37562015000000186. 